\title{
Diatoms in the Bottom Sediments of Two Closely Located Lakes in Khakassia
}

\author{
Galina N. Bolobanshchikova*a, \\ Maxim S. Kulikovskiy ${ }^{\mathrm{b}}$ and Denis Yu. Rogozin ${ }^{\mathrm{a}, \mathrm{c}}$ \\ ${ }^{a}$ Institute of Biophysics SB RAS \\ FRC "Krasnoyarsk Science Center SB RAS" \\ 50/50 Akademgorodok, Krasnoyarsk, 660036, Russia \\ ${ }^{b}$ K.A. Timiryazev Institute of Plant Physiology RAS \\ 35 Botanical Str., Moscow, 127276, Russia \\ 'Siberian Federal University \\ 79 Svobodny, Krasnoyarsk, 660041, Russia
}

Received 27.09.2018, received in revised form 10.11.2018, accepted 10.12.2018

\begin{abstract}
Diatoms are one of the main paleo-indicators of lake changes, as they are preserved in bottom sediments for centuries. The present study reports new data on diatoms in the bottom sediments of Lake Shira and compares them with diatoms from the bottom sediments of Lake Utichye-3, which is situated close to Lake Shira (Khakassia, Russia). The results showed that both lakes have undergone changes in the past, and the species compositions have changed several times. The dominant species in Lake Shira is now Cyclotella choctawhatcheeana Prasad, a planktonic marine species. Rhopalodia constricta (W. Smith) Krammer is a benthic brackish or freshwater species that often occurs in Lake Shira. The lower layers of sediments, dating from approximately the $17^{\text {th }}$ century, were dominated by the freshwater plankton species Aulacoseira ambigua (Grunow) Simonsen and A. italica (Ehrenberg) Simonsen; Staurosira venter sensu lato (Ehrenberg) Cleve \& JD Möller, a benthic freshwater species, also occurred there. The bottom sediments of Lake Utichye-3, with the exception of the lower layers, were dominated by C. meneghiniana Kützing (a planktonic brackish or freshwater species). This species was also found in the upper layers of the bottom sediments of Lake Shira. This suggests that conditions in Lake Shira and Lake Utichye-3 were once similar. Surirella peisonis Pantocsek (a marine species) prevailed in the lower layers of the core of Lake Utichye-3. Thus, we can say that the climatic conditions in the region where the lakes are situated have changed several times.
\end{abstract}

Keywords: paleolimnology, paleoclimate, diatoms, bottom sediments, salt lake, Aulacoseira sp., Cyclotella sp., Surirella sp., Rhopalodia sp.

(C) Siberian Federal University. All rights reserved

This work is licensed under a Creative Commons Attribution-NonCommercial 4.0 International License (CC BY-NC 4.0).

* Corresponding author E-mail address: galina.ibp@mail.ru 


\title{
Диатомовые водоросли \\ в донных отложениях двух близко расположенных соленых озер Хакасии
}

\author{
Г.Н. Болобанщикова \\ М.С. Куликовский \\ ${ }^{a}$ Институт биофизики СО РАН \\ ФИЦ «Красноярский научный центр СО РАН» \\ Россия, 660036, Красноярск, Академгородок, 50/50 \\ ${ }^{6}$ Институт физиологии растений им. К.А. Тимирязева РАН \\ Россия, 127276, Москва, ул. Ботаническая, 35 \\ ${ }^{6}$ Сибирский федеральный университет \\ Россия, 660041, Красноярск, пр. Свободныий, 79
}

В связи с тем, что диатомовые водоросли сохраняются в донных отложениях в течение многих столетий, они являются одним из основных палеоиндикаторов условий в водоеме. $B$ настоящей работе мы приводим новые сведения об остатках диатомовых в отложениях озера Шира, а также проводим сравнительный анализ диатомовых водорослей донных отложений озера Шира и близко расположенного к нему озера Утичье-3 (Хакассия, Россия). Результаты анализа показали, что оба озера в прошлом претерпевали изменения, а видовой состав неоднократно менялся. Доминирующим видом в озере Шира в настоящее время является Cyclotella choctawhatcheeana Prasad - планктонный, солоноводный вид, а также часто встречается Rhopalodia constricta (W. Smith) Krammer - бентосный, солоноватопресноводный вид. В нижних слоях донных отложений, приблизительно датируемых 17-ым веком, доминируют пресноводные, планктонные виды Aulacoseira ambigua (Grunow) Simonsen и A. italica (Ehrenberg) Simonsen, а также встречается Staurosira venter sensu lato (Ehrenberg) Cleve \& J.D.Möller - бентосный, пресноводный вид. В донных отложениях озера Утичье-3, за исключением нижних слоев, доминировала C. meneghiniana Kützing планктонный, солоновато-пресноводный вид, встречавшийся в незначительном количестве и в верхних слоях донных отложений озера Шира. В нижних слоях керна озера Утичье-3 доминировала Surirella cf. peisonis Pantocsek - солоноводный вид. Таким образом, можно сделать вывод, что климатические условия в регионе расположения озер неоднократно менялись.

Ключевые слова: палеолимнология, палеоклимат, диатомовые водоросли, донные отложения, соленые озера, Aulacoseira sp., Cyclotella sp., Surirella sp., Rhopalodia sp. 


\section{Introduction}

The bottom sediments of water bodies are among the best sources of retrospective climate data. In meromictic lakes, they retain their layered structure for long periods of time. The absence of oxygen in the bottom water layer is favourable for the conservation of materials that settle to the bottom. Because of their silicon frustules, diatom algae, which are among the best paleo-indicators of water body development, are preserved well in bottom sediments.

Lake Shira has long been a site chosen for studying the species composition and vertical distribution of phytoplankton (Popova, 1946; Aleksandrovskaya et al., 1959; Cherepnina, 1977; Kolmakov et al., 1993; Degermendzhy et al., 1996; Zotina et al., 1997; Zotina, 2001; Makeeva et al., 2012; Bolobanschikova et al., 2015). Materials collected in sediment traps were analysed in 2012 (Bolobanschikova et al., 2015). By 1996, the following diatoms had been identified in Lake Shira: Cyclotella choctawhatcheeana Prasad (Zotina, 2001), formerly known as Cyclotella tuberculate Makarova \& Loginova (Genkal, 2012), Diatoma vulgaris Bory, Navicula sp., Nitzschia sp., and Stephanodiscus sp., with C. choctawhatcheeana definitely dominating (Zotina, 2001).

The species composition of diatoms in one part of the bottom sediment core from Lake Shira was analysed in a previous study (Bolobanschikova et al., 2015). The purpose of this study was to investigate the species composition of diatoms in bottom sediments of two closely located lakes, Lake Shira and Lake Utichye-3, to reveal past changes in the conditions in the lakes and climate conditions of the region.

\section{Materials and Methods}

Lake Shira $\left(54^{\circ} 30^{\prime} \mathrm{N}, 90^{\circ} 11^{\prime} \mathrm{E}\right)$ is situated in the north of the Republic of Khakassia (Russia). The lake is meromictic, brackish (15-19 g/L of salt) (2002-2012), and weakly alkaline (pH 8.99.3). The lake area is $39.5 \mathrm{~km}^{2}$, and the maximum depth is $24 \mathrm{~m}$ (Rogozin et al., 2011). The lake has no outflow, and the inflow is via the Son River and atmospheric, underground, and anthropogenic water sources.

Lake Utichye-3 $\left(54^{\circ} 31^{\prime} \mathrm{N}, 90^{\circ} 28^{\prime} \mathrm{E}\right.$, the Republic of Khakassia, Russia) is located $23 \mathrm{~km}$ east of Lake Shira. Its area is $1.41 \mathrm{~km}^{2}$, and its shoreline length is $5.4 \mathrm{~km}$. The lake is of an oblong form, stretching $2.1 \mathrm{~km}$ northeast, and it is $1.2 \mathrm{~km}$ wide. The average depth of the lake is $2.5 \mathrm{~m}$, and the maximum depth is approximately $5.5 \mathrm{~m}$ (2008-2015). The mineral content of the water varies annually and seasonally between 7.9 and $5.9 \mathrm{~g} / \mathrm{L}$. The $\mathrm{pH}$ varies between weakly alkaline $(\mathrm{pH}=7.6)$ and alkaline $(\mathrm{pH}=8.3)$. The lake has no outflow, and the inflow is from ground, underground, and atmospheric water.

Sediment samples were collected in May 2011 (Lake Shira) and July 2012 (Lake Utichye-3) using a box corer designed at the Institute for Biology of Inland Waters RAS (Borok) (Abakumov et al., 1983). The sample collected from Lake Shira was $400 \mathrm{~mm}$ long (Fig. 1-1) (Bolobanschikova et al., 2015), and the sample from Lake Utichye-3 was $210 \mathrm{~mm}$ long (Fig. 1-2). In the laboratory, plastic tubes $\left(\mathrm{d}_{\text {inner }}=45 \mathrm{~mm}\right)$ were used to take cores from the samples. Then, both ends of each tube were sealed, and the tubes were stored at a temperature of $+4^{\circ} \mathrm{C}$ in a strictly vertical position. In the laboratory, the cores were cut longitudinally and divided into halves with two thin stainless steel plates inserted into the cleft. After the core was separated, the plates were removed by moving them transversely, and thus, the split surfaces, with their visible horizontal layered heterogeneities, remained intact. The core halves were kept in air under weak light for $24 \mathrm{~h}$ to achieve the most distinct colour differences. Then, a colour photograph 


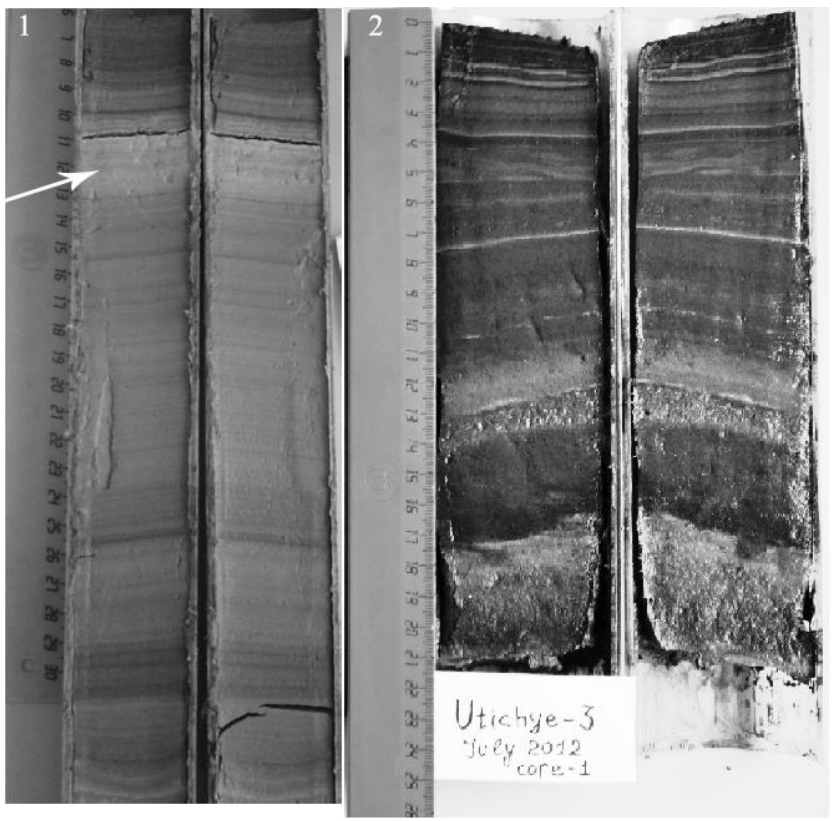

Fig. 1. Sediment cores: 1 - Lake Shira (Khakassia, May 2011, the arrow indicates the first carbonate layer); 2 Lake Utichye-3 (Khakassia, July 2012)

of each core with a fixed millimetre ruler was taken. The core halves were then sliced into 5-10 mm thick transverse samples. All samples were stored in the dark at a temperature of $-20^{\circ} \mathrm{C}$ in vacuum-sealed polyethylene bags (Rogozin et al., 2005). During sample collection, the upper layers of the core from Lake Shira were washed away and lost. Therefore, to obtain the same depth scale for all samples, we used the upper boundary of the first "white" layer as a reference point, which was set at $130 \mathrm{~mm}$ below the water-sediment interface (Fig. 1-1). The exact position of this boundary was determined previously (Kalugin et al., 2013). Visual counting of the layers showed that the upper boundary of the first "white" layer could be dated to 1945 (Kalugin et al., 2013). No dating was performed for the bottom sediments of Lake Utichye-3. The species composition and abundance of diatoms in the bottom sediments were determined using a method described elsewhere (Bolobanschikova et al., 2015).
In addition to the collection of bottom sediments, in 2012 and 2013, we used sediment traps at Lake Shira. The procedure of trap placement and sample collection and analysis is described in more detail elsewhere (Bolobanschikova et al., 2015). The traps were placed in the central deep-water part of the lake, close to $54^{\circ} 30^{\prime} 350 \mathrm{~N}, 90^{\circ} 11^{\prime} 350 \mathrm{E}$, for the following periods: 4 September -24 October in 2012, 24 October - 31 May, 16 March - 31 May, 31 May - 8 July, 10 July - 3 September, and 4 September - 23 October in 2013. The traps were suspended in the 13, 15, and $20 \mathrm{~m}$ layers. Two traps were placed in each layer; the data obtained for each layer were averaged.

Three $1.5 \mathrm{ml}$ samples of sediment were taken from each trap. The samples were placed in centrifuge tubes and dried in a drying cabinet for $24 \mathrm{~h}$ at a temperature of $100^{\circ} \mathrm{C}$. The remaining sediment was weighed to determine its dry weight, and an aliquot of approximately $0.05 \mathrm{mg}$ was taken. It was treated with a $30 \%$ hydrogen 
peroxide solution while being heated in a solid state thermostat to a temperature of $90^{\circ} \mathrm{C}$ for $4 \mathrm{~h}$, with hydrogen peroxide added continually (Abakumov et al., 1983). After cooling the samples, the hydrogen peroxide was removed by washing the samples 5 times in distilled water using centrifugation; then, each sample was diluted with distilled water to achieve a volume of $1.5 \mathrm{ml}$.

The valves of the diatoms were counted and photographed using a light microscope Axiovert (Zeiss, Germany) equipped with an oil immersion objective $(\times 100 /$ n.a.1.4, DIC $)$ and an electron microscope TM3000 (Hitachi, Japan). Determination of the sedimentation rate was based on the total number of cells in the trap, the time of deployment of the trap, and the cross-sectional area of the trap. These data were compared with the available data on the diatom sedimentation rate in 2012 (Bolobanschikova et al., 2015). Diatoms were identified using identification guides and taxonomic keys (Kützing, 1844; Zabelina et al., 1951; Krammer et al., 1988; Krammer et al., 1986; Krammer et al., 1991; Likhoshvai et al., 1997; LangeBertalot, 2001; Makarova, 2002; Genkal et al., 2009; Levkov, 2009; Genkal, 2012). The correctness of the authors' species names and the currently used species names were checked at http://algaebase.org.

\section{Results}

Seasonal dynamics of the sedimentation of diatoms in Lake Shira

Qualitative determination of the material from the traps showed that in all periods, the diatom community had been dominated by $C$. choctawhatcheeana. The samples also contained Cyclotella meneghiniana Kützing and a few representatives of Amphora sp., Synedra sp., Navicula sp., Cocconeis sp., and Rhopalodia sp.

The sedimentation rate of diatoms in Lake Shira in 2013 was the highest in summer and autumn (July-September), reaching $(8.3 \pm 2.5) \cdot 10^{8}$ cells $/\left(\mathrm{m}^{2} \cdot \mathrm{d}\right)$ (Fig. 2). The lowest sedimentation rate was recorded in spring (March-May); as in 2012, the number of sinking cells was the highest at a depth of $20 \mathrm{~m}:(0.2 \pm 0.2) \cdot 10^{8}$ cells $/\left(\mathrm{m}^{2} \cdot \mathrm{d}\right)$.

\section{Composition of diatoms}

in the sediments of Lake Shira

Analysis of the bottom sediments showed a non-uniform vertical distribution of diatoms in the core (Bolobanschikova et al., 2015). The presence of the valves of $C$. choctawhatcheeana and representatives of Cocconeis sp. and Nitzschia $\mathrm{sp}$. in the layers above the first carbonate layer at a depth of 60-110 mm (approximately 1980-1955) is indicative of the similarity between diatom composition at that time and the contemporary

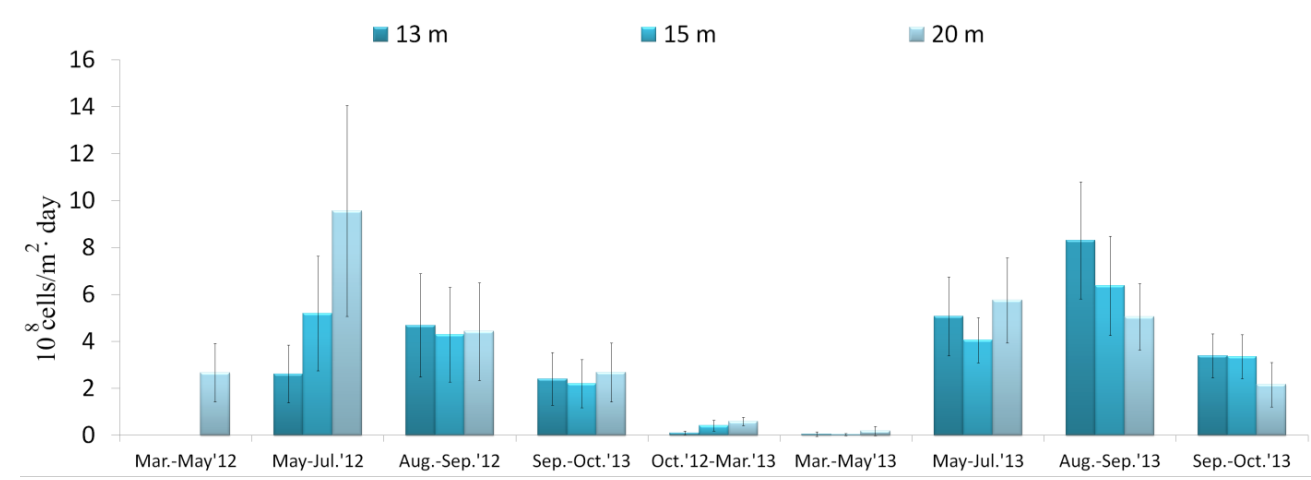

Fig. 2. Seasonal dynamics of the diatom sedimentation rate in Lake Shira in 2012-2013 
composition of diatoms in Lake Shira. The valves of Nitzschia cf. sigmoidea (Nitzsch) W. Smith, Aulacoseira italica (Ehrenberg) Simonsen, A. ambigua (Grunow) Simonsen, and Staurosira venter sensu lato found at a depth of 310-355 mm (approximately 1690-1627) presumably suggest a subsequent change in the species composition of diatoms in Lake Shira. In addition to the previously mentioned $C$. choctawhatcheeana (Bolobanschikova et al., 2015), layers above the first carbonate layer contained numerous partially destroyed valves of the brackish-water diatom Rhopalodia constricta (W. Smith) Krammer (Fig. 3).

\section{Composition of diatoms}

in the sediments of Lake Utichye-3

As dating of the layers of the core from Lake Utichye-3 was not performed, the results of the sediment analysis are presented as a description of the layers without approximate dates of their formation.

In contrast to the cores of Lake Shira, the frequency of occurrence of diatoms in the cores of Lake Utichye-3 was considerably higher, and diatoms were present in almost all layers. The diatoms in the core were dominated by C. meneghiniana (Fig. 4) except for the 41$44 \mathrm{~mm}$ layers and the layers between $92 \mathrm{~mm}$ and

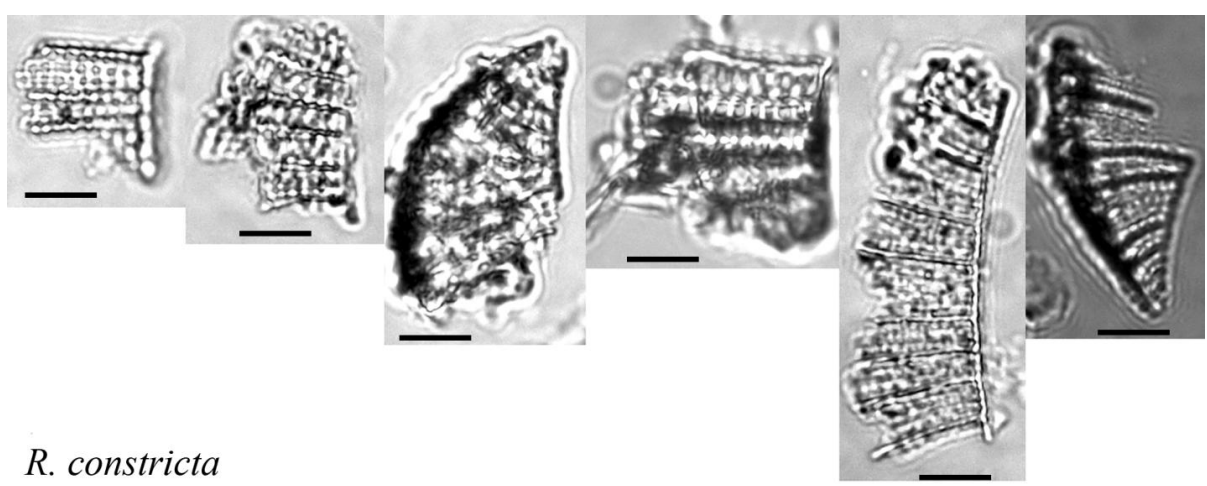

Fig. 3. Diatoms in the bottom sediments of Lake Shira, depth of 60-110 mm: parts of the shells of Rhopalodia constricta. Scale bars, $10 \mu \mathrm{m}$

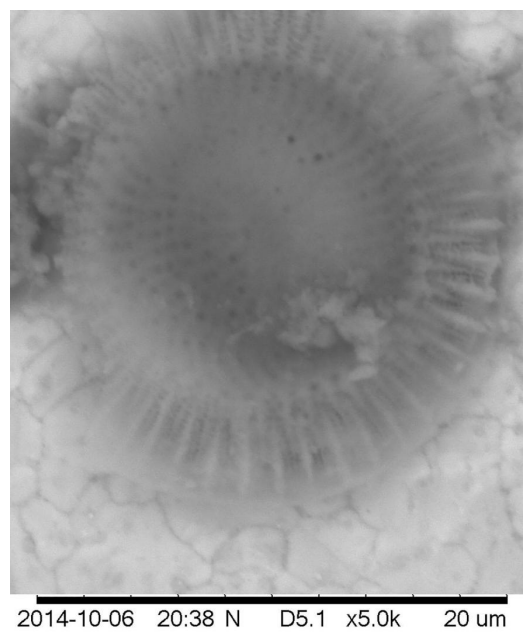

Fig. 4. Diatoms in the bottom sediments of Lake Utichye-3: Cyclotella meneghiniana 
$112 \mathrm{~mm}$. Diatoms found at a depth of 41-44 $\mathrm{mm}$ were dominated by Surirella $\mathrm{cf}$. peisonis (Fig. 5); this layer also contained numerous broken frustules of Surirella spp. (Fig. 6). The layers between $92 \mathrm{~mm}$ and $112 \mathrm{~mm}$ were dominated by Navicula sp. A few representatives of Amphora sp., Cocconeis lineata Ehrenberg, Cocconeis sp., Caloneis sp., Rhopalodia musculus (Kützing) Otto Müller, Navicula viridula (Kützing) Ehrenberg, Navicula sp., Paralia sp., and
Diploneis sp. and broken frustules of Achnanthes sp. (some of them tentatively identified) were found.

We determined the number of valves of diatoms in the bottom sediments of Lake Utichye-3 (Fig. 7) and observed peaks in the $0-2 \mathrm{~mm}, 51-$ $54 \mathrm{~mm}$, and $82-83 \mathrm{~mm}$ layers: $(152.8 \pm 47.7) \cdot 10^{6}$, $(323.3 \pm 101.1) \cdot 10^{6}$, and $(146.9 \pm 77.8) \cdot 10^{6}$ valves/g. No diatoms were found in the $112-119 \mathrm{~mm}, 145$ $152 \mathrm{~mm}$, or $165-210 \mathrm{~mm}$ layers.

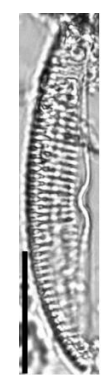

Diploneis sp

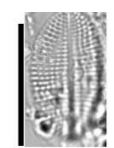

Cocconeis lineata

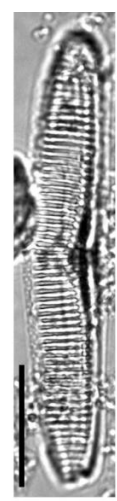

Caloneis sp

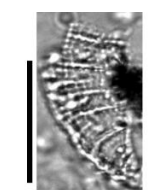

Rhopalodia musculus

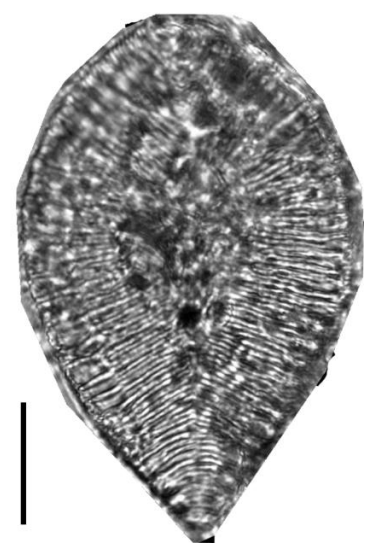

Surirella cf. peisonis

Fig. 5. Diatoms in the bottom sediments of Lake Utichye-3. Scale bars $10 \mu \mathrm{m}$
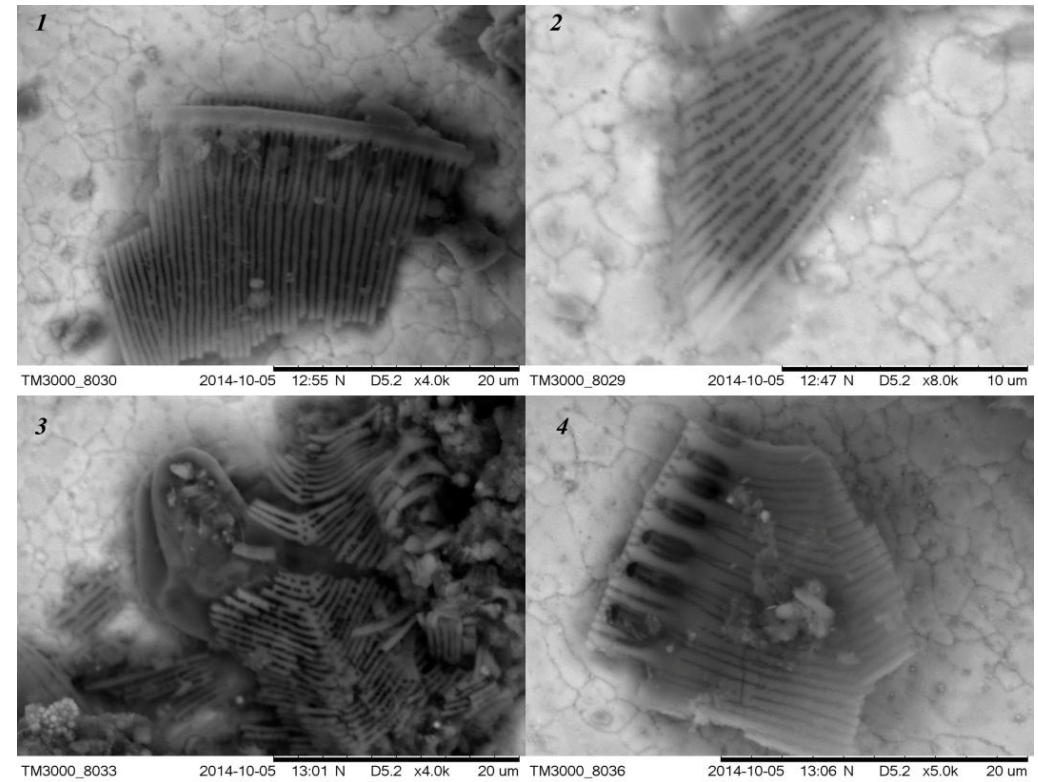

Fig. 6. Diatoms in the bottom sediments of Lake Utichye-3: parts of the shells of Surirella spp. 


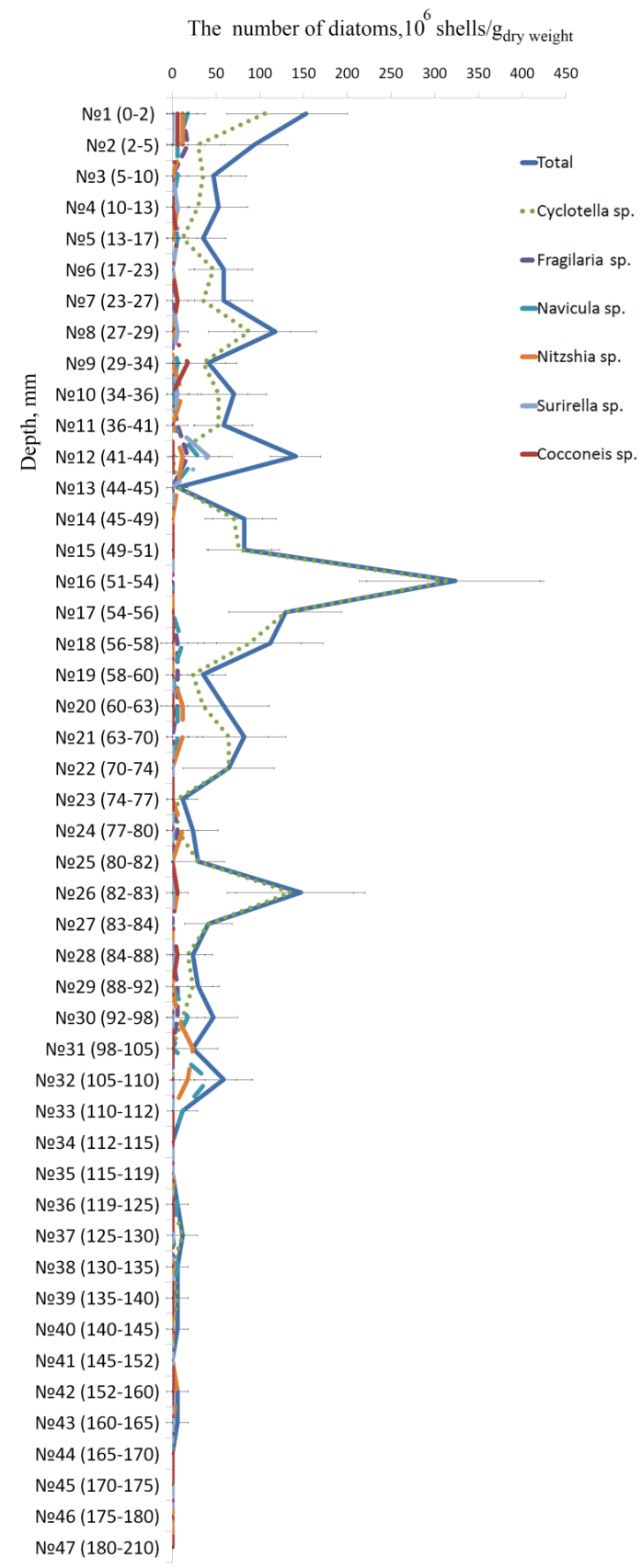

Fig. 7. Vertical profile of diatom numbers in the bottom sediments of Lake Utichye-3

\section{Discussion}

Analysis of samples of water and sedimentation material from Lake Shira shows that since 1946, the species composition of diatom algae has remained unchanged (Popova, 1946; Aleksandrovskaya et al., 1959; Cherepnina,
1977; Kolmakov et al., 1993; Degermendzhy et al., 1996; Zotina et al., 1997; Zotina, 2001; Makeeva et al., 2012; Bolobanschikova et al., 2015). C. choctawhatcheeana, which is a planktonic saltwater diatom that commonly occurs in eutrophic water bodies (Genkal, 
2012), has remained the dominant species. In addition to $C$. choctawhatcheeana, the samples contained numerous partially destroyed valves of $R$. constricta, a benthic brackish-freshwater species commonly occurring in water bodies with a low nitrogen to phosphorus ratio (Kützing, 1844; Krammer et al., 1988).

Examination of the core showed the nonuniformity of the vertical profile of diatom numbers in the upper portion of the bottom sediments collected from Lake Shira. Diatoms were only found in the core layers above the carbonate white layers; the other core layers contained no diatoms (Bolobanschikova et al., 2015).

Comparison of the trapped material with the core samples showed that the species composition of diatoms in Lake Shira since approximately 1946 has been similar to the contemporary species composition. However, the species composition of diatoms in the periods from 1690-1683 and 1655-1627 was different from their present-day composition. The presence of the valves of colonial species of alpine, arctic, and medium-latitude diatoms such as A. italica and A. ambigua (planktonic benthic indifferent mesotrophic species) and Staurosira venter sensu lato (a benthic indifferent oligotrophic species) suggests that in the mid and late $17^{\text {th }}$ century, Lake Shira was a mesotrophic lake with weakly alkaline water whose salinity was lower than it is now (hence, the lake was deeper). The presence of alpine-arctic species may be indicative of a colder climate, which is consistent with the Little Ice Age that occurred at that time.

Diatoms were poorly preserved in the sediments of Lake Shira, and the layers between $120 \mathrm{~mm}$ and $310 \mathrm{~mm}$ did not contain any diatoms, not even fragments of valves. The reasons for this could be the high mineral content of the lake water and high $\mathrm{pH}$, which is unfavourable for the conservation of the valves of diatoms.

A study by Flower et al. (2009) described an adverse effect of a more alkaline medium on the preservation of diatom shells. Other factors influencing the preservation of the shells are the rate of sedimentation and sediment accumulation and the concentration of diatoms: the higher these parameters and the lower the $\mathrm{pH}$ and temperature, the better the shells are preserved. In addition, the shells of diatoms are preserved better if other organisms, including bacteria, do not consume them at a high rate.

Researchers working at Lake Beloye (West Siberia, Russia) noted that the absence of diatoms in the white carbonate and mud layers could be associated with the increase in $\mathrm{pH}$ and, at the same time, with phosphorus and iron deficiencies caused by the abundance of calcium, which limits the activity of these elements (Krivonogov et al., 2012).

In a more alkaline medium, the silicon frustules of diatoms may dissolve after the cells die, which affects their preservation and, hence, the detection of the shells of diatoms in the layers corresponding to periods when the water in the lake was more alkaline. Moreover, lakes with high mineral contents and an alkaline $\mathrm{pH}$ cannot boast a high diversity of diatoms.

Analysis of the bottom sediments from Lake Utichye- 3 shows that in the recent past, the state of the lake has not changed significantly. The greater number of valves found in the middle part of the core may suggest a decrease in the mineral content of the lake water. The number of cells of the dominant diatom $C$. meneghiniana, which occurs in both saltwater and freshwater lakes, decreases in the deeper layers, and the number of cells of Surirella cf. peisonis, which is a saltwater species, increases, which may suggest a decrease in the water level of the lake and an increase in the water mineral content. 
A possible reason for the absence of the valves of diatoms in the $112-119 \mathrm{~mm}, 145-152 \mathrm{~mm}$, and $165-210 \mathrm{~mm}$ layers of the core from Lake Utichye- 3 may be that in the 1920 s, the lake dried up (Parnachev, 1999). During that period, no algal flora, including diatoms, could develop in the lake. The literature data (Parnachev, 1999) suggest that the precipitation of the first white carbonate layer and the drying up of Lake Utichye-3 occurred at the same time, when the water levels in all the lakes of the North Minusinsk Depression were considerably lower than they are now.

\section{Conclusion}

The comparison of the bottom sediments from Lake Shira and Lake Utichye-3 suggests that the species composition of diatoms in the water (trap samples) and bottom sediments above the first white carbonate layer in Lake Shira is similar to the species composition of the upper part of the core from Lake Utichye-3. Although the diatom community of Lake Shira is now dominated by C. choctawhatcheeana (a saltwater species), both cores contain C. meneghiniana. The data obtained in this study suggest that the conditions in Lake Shira and Lake Utichye-3 changed several times in the past, and those changes were caused by changes in the climate of the region.

\section{Acknowledgements}

This study was supported by the RFBR (Project No. 16-05-00091), the Integrated Program for Basic Research of SB RAS II.1 (Project "Biophysical and lithological-geochemical responses of lake sedimentation systems to climate change in the Late Holocene"), and Russian Science Foundation (14-14-00555) for M.K. for light microscopy.

\section{References}

Abakumov V.A., Bubnova N.P., Holikova N.I., Goridchenko T.P., Liepa R.A., Svirskaya N.L., Ganshina L.A., Semin V.A., Khromov V.M., Nikitin D.I., Katanskaya V.M., Raspopov I.M. (1983) Guidance on methods for the hydrobiological analysis of surface waters and bottom sediments. Leningrad, Hydrometeoizdat, 240 p. (in Russian)

Aleksandrovskaya M.A., Goncharova M.N., Komarova N.M., Malakhov A.M., Skornyakov V.A., Churakov V.K., Tsytsarin G.V., Shmideberg N.A. (1959) Hydromineral resources of the Lake Shira region (report on the works of 1957-1958). Vol. 1 (No 117), Vol. 2 (No 118). Moscow, Moscow State University, 500 p. (in Russian)

Bolobanschikova G.N., Rogozin D.Yu., Firsova A.D., Rodionova E.V., Degermendzhy N.N., Shabanov A.V. (2015) Analysis of diatom algae from the water column and bottom sediments of Shira Lake (Khakassia, Russia). Contemporary Problems of Ecology, 8(2): 173-185

Cherepnina G.I. (1977) Phytoplankton and its production on the south lakes of Krasnoyarsk Territory. The cycle of substances and energy in reservoirs. Elements of the biotic cycle. Theses of the $4^{\text {th }}$ All-Union Limnological Meeting. Listvenichnoe on Baikal, p. $74-77$ (in Russian)

Degermendzhy A.G., Zotina T.A., Tolomeyev A.P. (1996) Structural-functional components of Lake Shira ecosystem plankton community (review and experiment). Siberian Journal of Ecology [Sibirskij ekologicheskij zhurnal], 5: 439-452 (in Russian)

Flower R.J., Ryves D.B. (2009) Diatom preservation: differential preservation of sedimentary diatoms in two saline lakes. Acta Botanica Croatica, 68 (2): 381-399

Genkal S.I. (2012) Morphology, taxonomy, ecology, and distribution of Cyclotella choctawhatcheeana Prasad (Bacillariophyta). Inland Water Biology, 2: 169-177 
Genkal S.I., Trifonova I.S. (2009) Diatoms in the plankton of the Lake Ladoga and reservoirs of its basin. Rybinsk, Publishing house JSC "Rybinsk House of Press", 72 p. (in Russian)

Kalugin I., Darin A., Rogozin D., Tretyakov G. (2013) Seasonal and centennial cycles of carbonate mineralisation during the past 2500 years from varved sediment in Lake Shira, South Siberia. Quaternary International, 290-291: 245-252

Kolmakov V.I., Gaevsky N.A., Gold V.M., Dorovskih S.N., Korkin A.I. (1993) Study of Lake Shira phytoplankton. Krasnoyarsk, Krasnoyarsk State University, 20 p. (in Russian)

Krammer K., Lange-Bertalot H. (1986) Süsswasserflora von Mitteleuropa. Bacillariophyceae. Teil 1: Naviculaceae. Jena, VEB Gustav Fischer Verlag, 876 p.

Krammer K., Lange-Bertalot H. (1988) Süsswasserflora von Mitteleuropa. Bacillariophyceae. Teil 2: Epithemiaceae, Bacillariaceae, Surirellaceae. Jena, VEB Gustav Fischer Verlag, 536 p.

Krammer K., Lange-BertalotH.(1991) Süsswasserfloravon Mitteleuropa. Bacillariophyceae. Teil 3: Centrales, Fragilariaceae, Eunotiaceae. Stuttgart, Jena, VEB Gustav Fischer Verlag, $576 \mathrm{p}$.

Krivonogov S.K., Takahara H., Yamamuro M., Preis Y.I., Khazina I.V., Khazin L.B., Kuzmin Y.V., Safonova I.Y., Ignatova N.V. (2012) Regional to local environmental changes in southern Western Siberia: Evidence from biotic records of mid to late Holocene sediments of Lake Beloye. Palaeogeography, Palaeoclimatology, Palaeoecology, 331-332: 177-193

Kützing F.T. (1844) Die kieselschaligen Bacillarien oder Diatomeen. Nordhausen, 152 p.

Lange-Bertalot H. (2001) Diatoms of Europe: diatoms of the European inland waters and comparable habitats. Vol. 2. Navicula sensu stricto. 10 Genera separated from Navicula sensu lato. Frustulia. H. Lange-Bertalot (ed.) A.R.G. Gantner Verlag K.G., 526 p.

Levkov Z. (2009) Diatoms of Europe: Diatoms of the European Inland Waters and Comparable Habitats. Vol. 5. Amphora sensu lato. H. Lange-Bertalot (ed.) A.R.G. Gantner Verlag K.G., 916 p.

Likhoshvai E.V., Pomazkina G.V., Nikiteyeva T.A. (1997) Centric diatoms from Miocene deposits of the Baikal Rift Zone (Tunkinskaya basin). Geology and Geophysics [Geologiya i geofizika], 38 (9): 1445-1452 (in Russian)

Makarova I.V. (2002) Diatoms of Russia and neighboring countries. Fossil and modern. Vol. 2, Issue 3. St. Petersburg University, 193 p. (in Russian)

Makeeva E.G., Naumenko Yu.V. (2012) Data on the flora of bacillariophyta of Lake Shira (Khakassia, Russia). Contemporary Problems of Ecology, 5(3): 255-262

Parnachev V.P. (1999) Water Resources of Shirinsky District of the Republic of Khakassia. Tomsk, Tomsk University, 172 p. (in Russian)

Popova T.G. (1946) To the knowledge of the algal flora of the reservoirs of northern Khakassia. News of the West-Siberian branch of the Academy of Sciences of USSR. Series Biology, Part 1: 41-72 (in Russian)

Rogozin D.Yu., Pimenov N.V., Kosolapov D.B., Chan'kovskaya Yu.V., Degermendzhy A.G. (2005) Thin-layer vertical distributions of purple sulfur bacteria in chemocline zones of meromictic lakes Shira and Shunet (Khakassia). Doklady Biological Sciences, 400(1-6): 54-56

Rogozin D.Yu., Zykov V.V., Kalugin I.A., Daryin A.V., Degermendzhy A.G. (2011) Carotenoids of phototrophic organisms in bottom sediments of meromictic Lake Shira (Siberia, Russia) as an indicator of past stratification. Doklady Biological Sciences, 439: 228-231 
Zabelina M.M., Kiselev I.A., Proshkina-Lavrenko A.I., Sheshukova B.S. (1951) The identification key for freshwater algae of the USSR. Issue 4. Diatoms. Moscow, Sovetskaya nauka, 619 p. (in Russian)

Zotina T.A. (2001) Vertical distribution of phytoplankton in salt Lake Shira. Hydrobiological Journal, 37 (3): 35-44

Zotina T.A., Tolomeyev A.P. (1997) Species composition and vertical structure of phytoplankton and zooplankton of Lake Shira. Herald of the N.F. Katanov Khakas State University, Series 4 "Biology, Medicine, Chemistry”, 4: 69-71 (in Russian) 